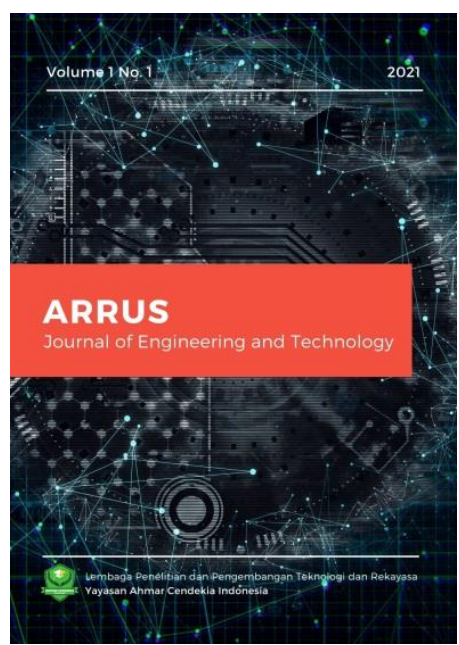

*Corresponding author: Muhammad Isradi, Department of Civil Engineering, Faculty of Engineering, Mercu Buana University, Jakarta, Indonesia

E-mail: isradi@mercubuana.ac.id
RESEARCH ARTICLE

\section{The Effectiveness of Users of the People's Crossing Bridge (JPO) at the Youth Center of the City of North Jakarta Administration during the COVID-19 Pandemic}

\author{
Muhammad Isradi ${ }^{*}$, Maulika Alifia Andri, Irfan Rifai, \& Amar Mufhidin \\ Department of Civil Engineering, Faculty of Engineering, Mercu Buana \\ University, Jakarta, Indonesia
}

\begin{abstract}
The current dense population of DKI Jakarta must be balanced with the provision of adequate transportation facilities and infrastructure. The current presence of pedestrians is usually concentrated in public facilities such as terminals, shopping centers, educational centers, and other public facilities. The existence of these pedestrians requires facilities for pedestrians, including road crossing facilities such as the People's Crossing Bridge (JPO), where the JPO is installed if it is required that there is no intersection between the flow of pedestrians and the flow of traffic. So that pedestrians want to use the JPO, it must be guaranteed safety and walking distance so that it does not get too far away. For this reason, this study was carried out to determine the effectiveness of the People's Crossing Bridge in the Youth Bracelet of the North Jakarta Administration. To determine the effectiveness of the pedestrian bridge at the Youth Center of North Jakarta City, the researchers observed the number of pedestrians for 2 days, namely during peak hours such as in the morning at $06.00-08.00$ and in the afternoon at 16.00 - 18.00. From the results of the research for 2 days in the field, it was found that almost $58 \%$ of people did not use JPO facilities, and only $42 \%$ of people used JPO facilities. Thus, it can be concluded that JPO at the Youth Center of North Jakarta City Administration is classified as a fairly effective JPO.
\end{abstract}

Keywords: effectiveness, North Jakarta Administrative City, people crossing bridge, JPO, youth center, COVID-19 
in life include facilitating the economy and culture, the flow of distribution of goods and services, as an access link between one region and another and can improve the economy and standard of living of the community. (Isradi \& Pratama, 2020)

The first Covid-19 was reported in Indonesia on March 2, 2020. On June 8, 2020, there were 32,033 confirmed cases and 1,883 deaths. So, in the month of Eid al-Fitr 1441 Hijriah which took place in Indonesia at the end of last May, at least the Covid-19 cases reached the range of 20,000 cases. (Nadine \& Imtiyaz, 2020)

The current dense population of DKI Jakarta must be balanced with the provision of adequate transportation facilities and infrastructure. The current presence of pedestrians is usually concentrated in public facilities such as terminals, shopping centers, educational centers and other public facilities. The existence of these pedestrians requires facilities for pedestrians, including road crossing facilities such as the People's Crossing Bridge (JPO), where the JPO is installed if it is required that there is no intersection between the flow of pedestrians and the flow of traffic. So that pedestrians want to use the JPO, it must be guaranteed safety and walking distance so that it does not get too far away.

Pedestrian Bridge is a physical facility for pedestrian crossings that is not on a plot for pedestrians which is built to minimize traffic conflicts with road crossings. The construction of a pedestrian bridge is recommended on a road section if the crossing facilities using a zebra cross and a pelican cross have disrupted existing traffic, the high frequency of accidents involving pedestrians, and the large volume of pedestrian traffic flows on the road section. (Kurniawan \& Ardi, 2018)

From observations in the field, the JPO in front of the Youth Center, located on Jalan Yos Sudarso, North Jakarta, is still not functioning optimally due to the fact that there are still pedestrians who choose to cross without using the pedestrian crossing facilities in front of the Youth Center, especially during the Pandemic. Covid-19.

One of the functions of this JPO is to serve users around the area, including for use by public and private employees, guests and the surrounding community who are carrying out work activities and carrying out daily activities as access to cross the toll road. assist pedestrians who will use Trans Jakarta transportation and want to cross to the Youth Center towards the North Jakarta Police Office or vice versa, but the pedestrian bridge at the location of the Youth Center road Jalan Yos Sudarso and vice versa, the pedestrians who will cross there are still crossing not using the bridge crossing. The condition of the pedestrian bridge location in front of the Youth Center Jalan Yos Sudarso shows the reluctance of pedestrians who do not use the pedestrian bridge which underlies this study to study the effectiveness and factors that influence the use of the pedestrian bridge.

Based on the above background, the researcher wants to know and analyze with the title "The Effectiveness of Users of the People's Crossing Bridge (JPO) at the Youth Center of the North Jakarta City Administration in the Covid-19 Pandemic Period" as part of fulfilling the graduation requirements in the UMB Civil Engineering Study Program, as well as to find out more about the effectiveness of pedestrian bridges in North Jakarta Administrative City.

\section{Literature Review}

\subsection{Transportation}

According to Morlok (1991), the definition of transportation is the transfer of people or goods from one place to another by using a vehicle that is driven by humans or machines. Transportation is used to make it easier for humans to carry out daily activities. According to Tamin (1997), transportation is a system consisting of facilities and infrastructure and a service system that allows movement throughout the region so that it accommodates 
population mobility, allows movement of goods, and allows access to all regions. Transportation itself is divided into 3 namely, land, sea and air transportation.

\subsection{Pedestrian}

Pedestrians are people who walk in road traffic spaces, both with and without assistive devices (Ministry of Public Works and Public Housing, 2018).Pedestrian ways are one of the eight elements of urban design (Shirvani, 1985). A good pedestrian system can reduce dependence on motorized vehicles in the city center, and vice versa can increase the number of pedestrian trips. One element of the pedestrian system is a pedestrian crossing facility. Crossing facilities create clear boundaries between pedestrians and motorized vehicles so as to provide safety guarantees for users. (Iswanto \& Setioko, 2020)

According to (Prima \& Prayogi, 2020) the factors that are influenced by pedestrian mileage include:

1) Time, the importance of walking affects the time of pedestrians. If walking to work is limited in time, the walking time is relatively fast, on the other hand, if the pedestrian is for recreation, the walking time will be relatively long.

2) Comfort, comfort in walking is also influenced by the existing environment and the condition of the pedestrians. The condition of the pedestrian path will function well for pedestrian comfort which includes:

a. Smoothness, the easier the route taken by pedestrians will increase the interest of pedestrians.

b. Distance/Long/Length, pedestrian paths should not be too long and create a lot of empty space, because it will be difficult to establish social contact between pedestrians.

c. Width / breadth, walking can be enjoyed when done together, therefore the width of the pedestrian path must be able to accommodate 2 or more people.

d. Vehicle Facilities, with parking far from the place of work will allow motorists.

\subsection{Definition of People's Crossing Facilities}

In (Ministry of Public Works and Public Housing, 2018) Guidelines for technical planning of pedestrian facilities. In Article 25 of Law Number 22 of 2009 it is stated that every road used for public traffic must be equipped with road equipment in the form of facilities for pedestrians and persons with disabilities. Based on these legal provisions, there is an obligation to provide adequate pedestrian facilities. Types of People's Crossing Facilities Groups are as follows:

\subsubsection{Plane Crossing}

(Directorate General of Land Transportation, 1997) Guidelines for the Engineering of Pedestrian Facilities in the City Area, level crossing facilities are:

1). Zebra cross

a. It must not be placed on a virtual island or at the mouth of an intersection.

b. Minor roads should be located 15 meters behind the stop line, and provided with road markings to direct vehicular traffic wherever possible.

c. Pay attention to the interaction of the priority system i.e. turning volume, speed and vision of the driver.

d. On roads with a width of more than 10 meters or more than 4 lanes protection is required.

2). Pelicans

a. Pelican crossings are placed at least 20 meters from the crossing. 


\subsubsection{Non-Planted Crossing}

Based on (Directorate General of Land Transportation, 1997) Guidelines for Engineering Pedestrian Facilities in the City Area, non-level crossing facilities and the requirements for placement of non-level crossing facilities are:

1). Pedestrian Bridge Construction of a pedestrian bridge is recommended to meet the following conditions:

a. If the crossing facilities using Zebra Cross and Pelicans are no longer possible to use.

b. Zebra Cross is already disrupting existing traffic.

2). Tunnels Tunnel construction is recommended to meet the following requirements:

a. If the crossing facilities using Zebra Cross and Pelican Cross and pedestrian bridges are not possible to use.

b. If the condition of the land allows for the construction of a tunnel.

Non-level crossings are recommended to be provided on roads that have the following criteria:

1) $\mathrm{PV}^{2}$ more than $2 \times 10^{8}$, pedestrian flow $(\mathrm{P})$ more than 1100 people per hour, vehicle flow (V) more than 750 vehicles per hour, taken from the average for 4 rush hours.

2) On a section with a design speed of $70 \mathrm{~km} /$ hour.

3) In a strategic area but does not allow pedestrians to cross the road other than the pedestrian bridge

4) must be equipped with road equipment in the form of facilities for pedestrians and people with disabilities.

Tabel 1. Types of Level Crossing Facilities

\begin{tabular}{ccccc}
\hline No & PV $^{2}$ & $\begin{array}{c}\text { P } \\
\text { (Person/hour) }\end{array}$ & $\begin{array}{c}\text { V } \\
\text { (Kend/hour) }\end{array}$ & Tipe Fasilitas \\
\hline 1 & $>10^{8}$ & $50-100$ & $300-500$ & Zebra Cross \\
2 & $>2 \times 10^{8}$ & $50-1100$ & $400-750$ & Zebra Cross with protector \\
3 & $>10^{8}$ & $50-1100$ & $>500$ & Pelican Cross \\
4 & $>10^{8}$ & $>1100$ & $>500$ & Pelican Cross \\
5 & $>2 \times 10^{8}$ & $50-1100$ & $>700$ & Pelican Cross with protector \\
6 & $>2 \times 10^{8}$ & $>1100$ & $>400$ & Pelican Cross with protector \\
\hline
\end{tabular}

Tabel 2. Type of Non-Planted Crossing Facility

\begin{tabular}{ccccc}
\hline No & PV $^{2}$ & $\begin{array}{c}\text { P } \\
\text { (Person/hour) }\end{array}$ & $\begin{array}{c}\text { V } \\
\text { (Kend/hour) }\end{array}$ & Tipe Fasilitas \\
\hline 1 & $>10^{8}$ & $100-1250$ & $2000-50000$ & Zebra Cross \\
2 & $>1 \times 10^{10}$ & $3500-1250$ & $400-750$ & Zebra Cross or Pelican Cross \\
3 & $>5 \times 10^{9}$ & $100-1250$ & $>5000$ & Pelican Cross or Crossing Bridge \\
4 & $>5 \times 10^{9}$ & $>1250$ & $>2000$ & Pelican Cross or Crossing Bridge \\
5 & $>1 \times 10^{10}$ & $100-1250$ & $>7000$ & Crossing Bridge \\
6 & $>1 \times 10^{10}$ & $>1250$ & $>3500$ & Crossing Bridge \\
\hline
\end{tabular}

where:

$\mathrm{P}=$ Traffic flow for pedestrian crossings along 100 meters, expressed in people/hour;

$\mathrm{V}=$ Traffic flow of two-way vehicles per hour, expressed vehicles/hour. 


\subsection{People Crossing Bridge Requirements}

Based on (Directorate General of Land Transportation, 1997) concerning Engineering for Pedestrian Facilities in the City Area where the Cross Bridge Requirements must be met for the construction of pedestrian bridges to conform to those specified/required in accordance with aspects of safety, comfort and convenience for pedestrians, then things - it should be noted that:

1) The vertical freedom between the bridge and the road is $5.0 \mathrm{~m}$.

2) The length of the descent path is at least $1.5 \mathrm{~m}$.

3) The maximum height of the steps is $15 \mathrm{~cm}$ and the width of the steps is $30 \mathrm{~cm}$.

4) The width of the stairway and walkway is a minimum of $2.0 \mathrm{~m}$.

5) The maximum slope is $10 \%$.
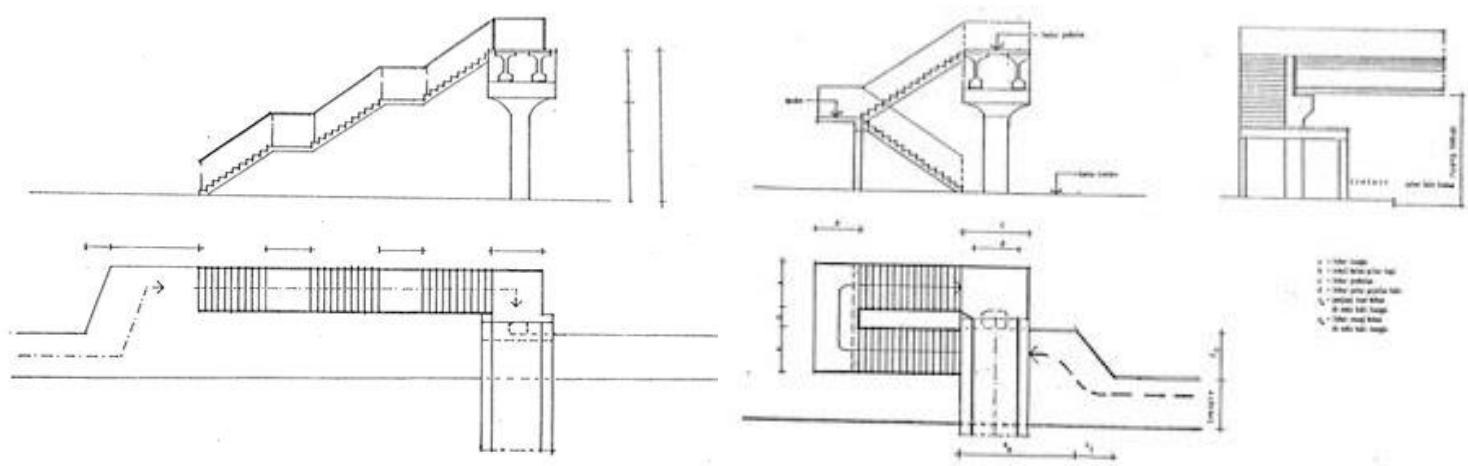

Figure 1. Drawings of "L" \& "U" Shaped Stair Plans

\subsection{Pedestrian Bridge Effectiveness Standard}

Standards for Effectiveness of Pedestrian Bridges, based on (Department of Public Works, Directorate General of Highways, Directorate of Technical Development, 1995) Guidelines for Planning Procedures for Pedestrian Facilities in Urban Areas, where the factors that are considered so that pedestrian bridges provide maximum benefits for pedestrians are:

a. The freedom to walk to precede and the freedom to pass other pedestrians without touching.

b. Ability to overtake other pedestrians.

c. Provide an optimal level of pedestrian comfort such as distance traveled, slope factor and pedestrian signs to make it easier for pedestrians to cross the pedestrian bridge.

d. Provide a level of security for pedestrians with lighting, a barrier with vehicle traffic.

\subsection{Effectiveness}

Based on the journal (Nadjam et al., 2018) that, "Effectiveness is a measure that states how far (quantity, quality, and time) has been achieved. Where the greater the percentage of targets achieved, the higher the effectiveness". The general and most prominent measures of effectiveness are:

1) Program success

2) Target success

3) Satisfaction with the program

4) Input and output levels

5) Achievement of overarching goals 
The effectiveness of the pedestrian bridge is calculated by the following equation:

Effectiveness $(\%)=\frac{A}{B} \times 100 \%$

where:

$A=$ Number of pedestrians crossing using a pedestrian bridge

$\mathrm{B}=$ Total number of pedestrians crossing the road.

The effectiveness of the pedestrian crossing bridge (Jpo) users can be determined by observing the intensity of the Jpo users at certain hours. In accordance with the parameters of the effectiveness of the pedestrian bridge, the criteria for assessing the effectiveness of JPO users are viewed from the percentage of the volume of pedestrians passing through the JPO as well as Arikunto Suharsimi's opinion, as follows:

0.800 to 1000 is classified as High

0.600 to 0.800 is classified as quite high

0.400 to 0.600 is classified as a bit low

0.200 to 0.400 is classified as Low

0.000 to 0.200 is classified as Very Low

In other words, the ratio of the percentage of the crossing volume to the value of

The effectiveness of pedestrian bridges can be classified into 5 categories. The classification can be seen in the table below.

Table 3. Percentage of JPO Effectiveness

\begin{tabular}{cc}
\hline Presentase & Criteria \\
\hline $0-20$ & Very ineffective \\
$21-40$ & Ineffective \\
$41-60$ & Enough \\
$61-80$ & Effective \\
$81-100$ & Very effective \\
\hline
\end{tabular}

\section{Research Method and Materials}

In this research method, it can be carried out in the parking area at the location of the place for research is the People's Crossing Bridge (JPO) precisely in front of the Youth Center which is located on Jalan Yos Sudarso, North Jakarta Administration. The method used in this study is the method of observation and literature. The observation method is a data collection technique by observing, recording the state of the target object, the literature method is an activity technique in collecting library data, identifying, and processing written data obtained. In this data collection is the next step after the preparation stage before conducting this research. The data obtained is in accordance with the plan in the research to be precise and appropriate. The data used as reference material in conducting research in compiling this final report is divided into two types of data, namely primary and secondary:

\subsection{Primary data}

This primary data can be surveyed directly in the field and some observations in the study include:

1) Average number of daily users.

2) Specifications for the pedestrian bridge (JPO). 
3) Survey Questionnaire.

\subsection{Secondary data}

This secondary data is obtained from related institutions or themselves, the data to be taken in the research are as follows:

1) Location map.

2) Population.

\subsection{Data Collection Time}

At the time of data collection can be obtained for 2 days, namely; Tuesday, April 20, 2021 and Sunday, April 25, 2021 to be picked up at 06.00 to $08.00 \mathrm{WIB}$ (GMT+7) and 16.00 to $18.00 \mathrm{WIB}(\mathrm{GMT}+7)$.
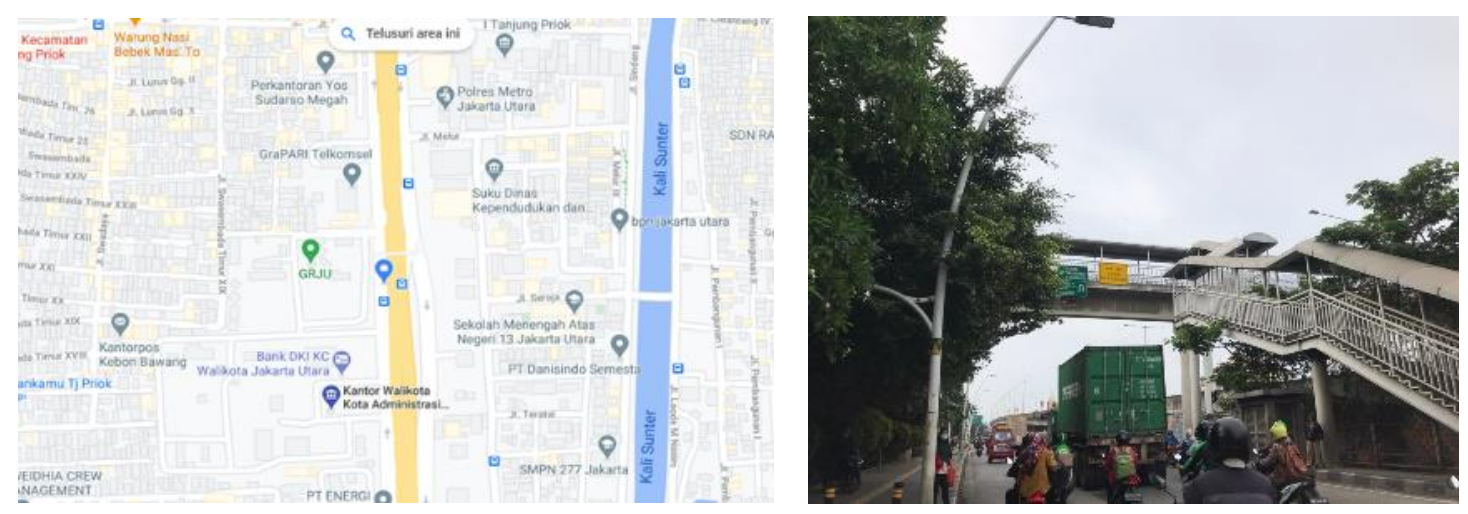

Figure 2. Image of the Location of the People's Crossing Bridge (JPO)

4. Results and Discussion

\subsection{Analysis of the Effectiveness of the People's Crossing Bridge}

Assessment of the effectiveness of pedestrian bridges using the following equation:

The effectiveness of the pedestrian bridge:

$$
(\%)=\frac{A}{B} \times \% 100
$$

where:

$\mathrm{A}=$ The number of pedestrians crossing using the pedestrian bridge

$\mathrm{B}=$ Total number of pedestrians crossing the road

From the results of the survey, the volume of pedestrians in front of the Youth Center located on Jalan Yos Sudarso, North Jakarta Administration City, with the results of the analysis as presented in the table 4 .

Table 4. Results of Analysis of the Volume of Crossers on April 20, 2021

\begin{tabular}{cccc}
\hline User JPO & Use JPO & Do Not Use JPO & Total \\
\hline $06.00-06.15$ & 2 & 7 & 9 \\
$06.15-06.30$ & 7 & 5 & 12 \\
$06.30-06.45$ & 6 & 12 & 18 \\
$06.45-07.00$ & 8 & 9 & 17 \\
$07.00-07.15$ & 13 & 13 & 26 \\
\hline
\end{tabular}




\begin{tabular}{cccc}
\hline User JPO & Use JPO & Do Not Use JPO & Total \\
\hline $07.15-07.30$ & 6 & 10 & 16 \\
$07.30-07.45$ & 7 & 17 & 24 \\
$07.45-08.00$ & 14 & 15 & 29 \\
$16.00-16.15$ & 2 & 7 & 9 \\
$16.15-16.30$ & 7 & 5 & 12 \\
$16.30-16.45$ & 6 & 12 & 18 \\
$16.45-17.00$ & 8 & 9 & 17 \\
$17.00-17.15$ & 13 & 13 & 26 \\
$17.15-17.30$ & 6 & 10 & 16 \\
$17.30-17.45$ & 7 & 17 & 24 \\
$17.45-18.00$ & 14 & 15 & 29 \\
\hline Total & 126 & 176 & 302 \\
\hline Persentase & $42 \%$ & $58 \%$ & \\
\hline Conclusion & & Effective enough \\
\hline
\end{tabular}

From the results of the analysis (table 4), the number of pedestrians on Tuesday, April 20, 2021, as many as 126 people (42\%) crossed using a pedestrian bridge and 176 people (58\%) crossed without using a pedestrian bridge. Meanwhile, from the graph of JPO utilization, the peak hours of JPO utilization in front of the Youth Center of North Jakarta City Administration occurred at 07.30-07.45 and 17.30-17.45 wib, namely 17 people.

The results of the survey conducted on Sunday, April 25, 2021, can be seen in the table 5 .

Table 5. Results of Analysis of the Volume of Crossers on April 25, 2021

\begin{tabular}{cccc}
\hline User JPO & Use JPO & Do Not Use JPO & Total \\
\hline $06.00-06.15$ & 1 & 2 & 3 \\
$06.15-06.30$ & 1 & 1 & 2 \\
$06.30-06.45$ & 2 & 2 & 4 \\
$06.45-07.00$ & 1 & 1 & 2 \\
$07.00-07.15$ & 2 & 1 & 3 \\
$07.15-07.30$ & - & 1 & 1 \\
$07.30-07.45$ & 1 & 2 & 3 \\
$07.45-08.00$ & 3 & 2 & 5 \\
$16.00-16.15$ & 3 & 1 & 4 \\
$16.15-16.30$ & 2 & 2 & 4 \\
$16.30-16.45$ & - & 2 & 2 \\
$16.45-17.00$ & 2 & - & 2 \\
$17.00-17.15$ & 2 & - & 2 \\
$17.15-17.30$ & - & 1 & 1 \\
$17.30-17.45$ & 1 & 4 & 5 \\
$17.45-18.00$ & - & 2 & 2 \\
\hline
\end{tabular}




\begin{tabular}{cccc}
\hline User JPO & Use JPO & Do Not Use JPO & Total \\
\hline Total & 21 & 24 & 45 \\
\hline Persentase & $47 \%$ & $53 \%$ & \\
\hline Conclusion & \multicolumn{2}{c}{ Effective enough } \\
\hline
\end{tabular}

From the results of the analysis (table 5), it was found that the number of pedestrians on Saturday, April 25, 2021, as many as 21 people (47\%) crossed using a pedestrian bridge and 24 people (53\%) crossed without using a pedestrian bridge. Meanwhile, from the graph of JPO utilization, the peak hour of JPO utilization in front of the Youth Center of North Jakarta City Administration occurred at 17.30-17.45 wib, namely 4 people.

Thus, based on the results of a survey for 2 days and the results of the analysis, it is found that there are more pedestrians who cross without using a pedestrian bridge compared to crossing using a JPO. Because the number of pedestrians who use JPO has an average of $42-47 \%$ per day. Thus, according to the Journal of Nadjam et al., 2018 the Percentage of Effectiveness of the JPO table can be classified that the People's Crossing Bridge in front of the Youth Center of North Jakarta City Administration is quite effective.

\subsection{Analysis of the Progress of the People's Crossing Bridge in the next 5 years}

The progress of pedestrians in the next 5 years is quite influential for the activities of the pedestrian crossing, where the number of pedestrian growth will be calculated by the following formula.

$$
\sum_{5}(1+\mathrm{i})^{\mathrm{n}}
$$

Information:

$\sum_{5}=$ the highest number of JPO users per day

$\mathrm{i}=$ User Growth

$\mathrm{n}=$ Progress Value

using the assumption of user growth (i) as $10 \%$, the following results are obtained:

$$
\sum_{5}(1+\mathrm{i})^{\mathrm{n}}=29 \times(1+0,1)^{5}=40 \text { orang }
$$

Based on the information, the author takes the number of progress for the next 5 years as many as 40 people will pass the People's Crossing Bridge.

This research was conducted distributing questionnaires directly to pedestrians. In this study, the number of questionnaires distributed was 100 copies. The returned questionnaire was the same number, ie 100 copies (response rate 100\%). All questionnaires distributed were complete and eligible for analysis.

Table 6. Questionnaire Return Rate

\begin{tabular}{cc}
\hline Description & Total \\
\hline Questionnaire Distribution & 65 \\
Return Questionnaire & 65 \\
Rate of Return & $100 \%$ \\
Questionnaire cannot be analyzed & 0 \\
Analyzeable questionnaire & 65 \\
\hline Source: Author Processed Data, 2021
\end{tabular}


The characteristics of the respondents in this study were divided into several categories, namely: Name, Gender, Age and Frequency of JPO use.

The number of samples, taken from the existing population according to the Slovin formula, follows the mathematical formula as follows. (Wibowo et al., 2019)

$$
n=\frac{N}{1+N(e)^{2}}
$$

where:

$\mathrm{n}=$ number of samples (determined from the formula above)

$\mathrm{N}=$ Populasi

$\mathrm{e}=$ Fault tolerance limit

by using an error tolerance limit of $10 \%(0.1)$, then the minimum sample in this study can be determined as follows:

$$
n=\frac{176}{1+176(0,1)^{2}}=63,76 \text { responden }
$$

Based on the formula, the authors took a sample of 65 people.

\subsection{Analysis of the Characteristics and Users of the Pedestrian Bridge in Front of the Youth Center, North Jakarta Administration.}

Recapitulation of the Number of Respondents by Age at the JPO Arena for Youth, North Jakarta Administration, the number of respondents based on age is presented in the table below.

Table 7. Recapitulation of Number of Respondents by Age

\begin{tabular}{ccc}
\hline Age & Respondent & Presentase \\
\hline $13-23$ & 16 & $24,61 \%$ \\
$24-30$ & 9 & $13,85 \%$ \\
$31-40$ & 11 & $16,92 \%$ \\
$>40$ & 29 & $44,62 \%$ \\
Total & 65 & $100 \%$ \\
\hline
\end{tabular}

Based on the results of the analysis in table 7 , the number of respondents for the age range $13-23$ years is 16 people $(24.71 \%)$. Age $24-30$ years the number of respondents as many as 9 people $(13.85 \%)$. Age $31-40$ years the number of respondents as many as 11 people $(16.92 \%)$. Age $>40$ years, the number of respondents was 29 people $(44.62 \%)$. So the total respondents were 65 respondents.

Recapitulation of the Number of Respondents by Gender at the JPO Arena for Youth, North Jakarta Administration, the number of respondents based on gender is presented in the table 8 .

Table 8. Recapitulation of the Number of Respondents by Gender

\begin{tabular}{ccc}
\hline Age & Respondent & Presentase \\
\hline Male & 34 & $52,30 \%$ \\
Female & 31 & $47,70 \%$ \\
Total & 65 & $100 \%$ \\
\hline
\end{tabular}


Based on the results of the analysis in Table 8, the percentage of the number of respondents based on gender is obtained. For female respondents as many as 34 people $(52.30 \%)$ and male respondents as many as 31 people $(47.70 \%)$.

Recapitulation of Number of Respondents Based on Intensity of Use After conducting a survey on the JPO in front of the North Jakarta Administration City Youth Center, the number of respondents based on the intensity of use is presented in the tab

Table 9. Number of Respondents Based on Intensity of Use

\begin{tabular}{ccc}
\hline Age & Respondent & Percentage \\
\hline Often & 14 & $21,54 \%$ \\
Seldom & 51 & $78,46 \%$ \\
Never & 0 & $0 \%$ \\
Total & 65 & $100 \%$ \\
\hline
\end{tabular}

Based on the results of the analysis in table 9 , it is obtained the percentage of the number of respondents based on the intensity of use. For respondents with the intensity of frequent use, as many as 14 people $(21.54 \%)$, for respondents with the intensity of Rarely, as many as 51 people $(78.46 \%)$, and there are no respondents with the intensity of rarely using.

\subsection{Validitas Test}

Validity Test Conducted to determine whether the measuring instrument (instrument/questionnaire) that has been compiled is said to be valid or not. Based on the questionnaire data from the research analysis of the factors that influence the use of JPO, it is declared valid and valid which is presented in the table 10.

Table 10. Validity Test Results

\begin{tabular}{cccccc}
\hline $\begin{array}{c}\text { Value } \\
\text { Weight }\end{array}$ & $\begin{array}{c}\text { Scale Mean If } \\
\text { Item Deleted }\end{array}$ & $\begin{array}{c}\text { Variance If } \\
\text { Item Deleted }\end{array}$ & $\begin{array}{c}\text { Item-Total } \\
\text { Correlation }\end{array}$ & $\begin{array}{c}\text { Alpha If Item } \\
\text { Deleted }\end{array}$ & Description \\
\hline X1.1 & 44.14 & 51.027 & .609 & .843 & Valid \\
X1.2 & 44.20 & 50.663 & .766 & .836 & Valid \\
X1.3 & 44.02 & 53.297 & .542 & .849 & Valid \\
X2.1 & 44.42 & 50.215 & .557 & .846 & Valid \\
X2.2 & 44.31 & 51.654 & .581 & .845 & Valid \\
X2.3 & 43.95 & 52.982 & .635 & .845 & Valid \\
X2.4 & 44.37 & 49.268 & .695 & .837 & Valid \\
X2.5 & 44.60 & 48.869 & .584 & .844 & Valid \\
X3.1 & 44.48 & 50.003 & .446 & .857 & Valid \\
X3.2 & 44.45 & 51.563 & .360 & .864 & Valid \\
X3.3 & 44.32 & 50.566 & .442 & .856 & Valid \\
X3.4 & 43.97 & 53.530 & .527 & .850 & Valid \\
\hline
\end{tabular}

In table 10, all the numbers in the Corrected Item-Total Correlation column have values above 0.300 (more than 0.3 ). This means that all statement items on the product variable questionnaire are valid. 


\subsection{Reliability Test}

The reliability test is intended to measure the questionnaire which is an indicator of the variables, along with the results of the reliability test of the questionnaire which is an indicator of the factors of using JPO

Table 11. Reliability Test Results

\begin{tabular}{cc}
\hline Croncach's Alpha & N of items \\
\hline .859 & 12 \\
\hline
\end{tabular}

From table 11, it can be seen that the alpha is quite large, which is above .859 , which means 0.859 . Cronbach's Alpha value is 0.859 or greater than 0.700 . This means that the product variable questionnaire is reliable. So that, it can be said that the variables from the questionnaire are valid and reliable.

\subsection{Normality test}

The data obtained from the respondents in this study were tested for normality to determine whether the data were normally distributed or not.

Table 12. Normality Test Results One-Sample Kolmogorov-Smirnov Test

\begin{tabular}{|ll|r|}
\hline & & Unstandardized Residual \\
\hline $\mathrm{N}$ & & 65 \\
Normal Parameters & Mean & .0000000 \\
& Std. Deviation & 3.71923741 \\
Most Extreme Differences & Absolute & .123 \\
& Positive & .080 \\
& Negative & -.123 \\
Test Statistic & & .123 \\
Asymp. Sig. (2-tailed) & & .015 \\
& & \\
\hline
\end{tabular}

From table 12, it is known that the results of the Kolmogorov-Smirnov Sample test show that the Asymp value. Sig. (2-tailed) .015 where in terms of a residual is said to be normally distributed in a simple way, it is by checking the residual value in the Asymp section. Sig. (2tailed) has a value $>0.05$ (or the Asymp Sig. value is greater than 5\%). From the table data above, it can be said that the residuals are normally distributed with a value of more than 0.005 , namely 0.015 .

Based on the output figure 3, where the plotting points contained in the picture "normal PP Plot of Regression Standardized Residual" always follow and approach the diagonal line. Therefore, as the basis for decision-making guidelines in the normality test of the probability plot technique, it can be concluded that the residual value is normally distributed. Thus, the assumption of normality for the residual value in the simple linear regression analysis in this study can be fulfilled. So it can be interpreted that all these variables are relevant to affect the use of pedestrian bridges.

\subsection{Data Recapitulation of Questionnaire Results}

Recapitulation of Number of Respondents Based on Usage after conducting a survey on the JPO in front of the City Administration Youth Center. 


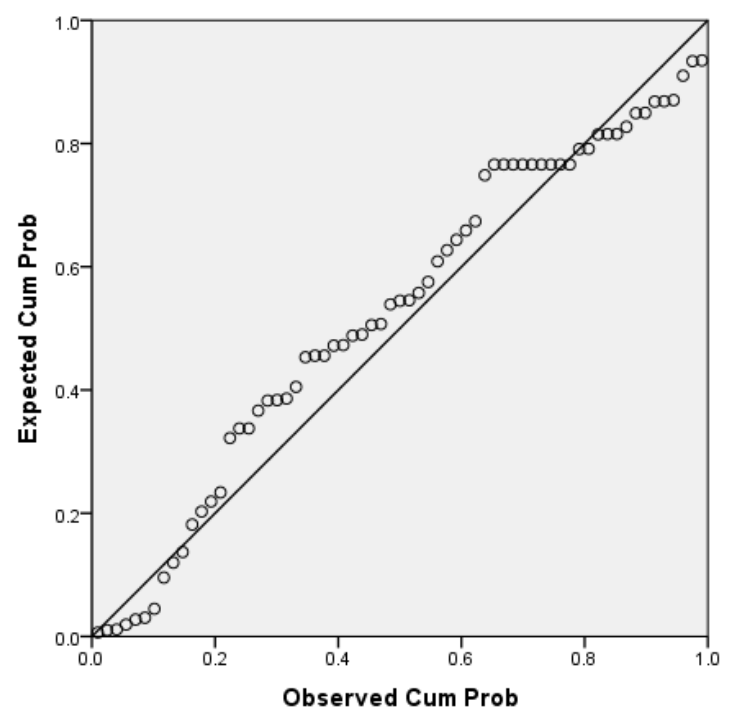

Figure 3. Probability Plot Normality Test Diagram Figure

Table 13. Recapitulation of Factors Affecting JPO

\begin{tabular}{ccccccc}
\hline Value Weight & 5 & 4 & 3 & 2 & 1 & Mean \\
\hline X1.1 & 29 & 22 & 9 & 5 & - & 4.15 \\
X1.2 & 23 & 26 & 15 & 1 & - & 4.09 \\
X1.3 & 28 & 30 & 4 & 3 & - & 4.28 \\
X2.1 & 19 & 31 & 7 & 4 & 4 & 3.88 \\
X2.2 & 20 & 30 & 9 & 6 & - & 3.98 \\
X2.3 & 31 & 25 & 9 & - & - & 4.34 \\
X2.4 & 23 & 21 & 14 & 7 & - & 3.92 \\
X2.5 & 22 & 16 & 14 & 11 & 2 & 3.69 \\
X3.1 & 25 & 22 & 6 & 5 & 7 & 3.82 \\
X3.2 & 27 & 19 & 7 & 6 & 6 & 3.85 \\
X3.3 & 30 & 18 & 7 & 5 & 5 & 3.97 \\
X3.4 & 33 & 20 & 12 & - & - & 4.32 \\
Total & 310 & 280 & 113 & 53 & 24 & \\
\hline
\end{tabular}

Based on the results of the table 13, the percentage of the number of questions obtained is based on the questionnaire. For question Number 3, where the JPO can be seen clearly from the side of the road, $89 \%$ of the respondents agreed, which means that the respondent agrees with the location of the JPO which can be seen clearly. As for question number 8 , where the JPO design is attractive, $58 \%$ of the respondents agree that the JPO design is attractive.

\section{Conclusion}

Based on the results of data analysis that has been carried out in this study, the conclusions obtained are as follows:

(1) Based on field research, it was found that the number of people crossing the People's Crossing Bridge during the pandemic on Tuesday, April 20, 2021, was 126 people using the JPO facility, while 176 people crossed carelessly. Meanwhile, on Sunday, April 25, 
2021, 21 people used the JPO facility and 24 people crossed carelessly. So a total of 2 days resulted in 147 people using the JPO facility.

(2) From the results of research for 2 days in the field, it was found that almost $58 \%$ of people did not use JPO facilities and only $42 \%$ of people used JPO facilities. Thus, it can be concluded that JPO at the Youth Center of North Jakarta City Administration is classified as a fairly effective JPO.

(3) From the factors obtained in the questions that have been distributed through the Questionnaire, it was found that the factor of the pedestrians using the JPO in the youth arena seen from the location of the JPO which can be seen clearly, this question got $89 \%$ of people agree. So that the JPO can be easily seen and used by pedestrians.

(4) Based on the data that has been obtained, we can assume that the progress of the Youth Crossing Bridge of the North Jakarta City Administration in the next 5 years will be as many as 40 people at every busy hour every day. Where this amount can be said that in the next 5 years this JPO will be very effective for pedestrians.

\section{References}

Isradi, M., \& Pratama, E. A. (2020). Performance analysis of Unsignal Intersection and Road section with MKJI Method 1997. IJTI (International Journal of Transportation and Infrastructure), 4(1), 1-11. https://doi.org/10.29138/ijti.v4i1.1160

Iswanto, B., \& Setioko, B. (2020). Faktor yang Mempengarubi Pejalan Kaki dalam Memilib Lokasi Penyeberangan Jalan di Kawasan Malioboro Yogyakarta. JURNAL PEMBANGUNAN WILAYAH \& KOTA, 16(2), 112-119. https://doi.org/10.14710/pwk.v16i2.26143

Janna, N. M. (2020). Konsep uji validitas dan reliabilitas dengan menggunakan spss. Osf, 2(1), 1-13.

Kementerian Pekerjaan Umum Direktorat Jendral Bina Marga. (1995). Permen PU No. 011/T/Bt/1995, Tentang Pedoman Tata cara Perencanaan Fasilitas Pejalan Kaki di Kawasan Perkotaan.

Kementrian Pekerjaan Umum Perumahan Rakyat, 2018, Permen PUPR No. 02/SE/M/2018, Tentang Pedoman Perencanaan teknis fasilitas pejalan kaki. SE Menteri PUPR, 5-6.

Khozidah, S., \& Muttaqin, M. zaenal. (2020). Evaluasi Fasilitas Pejalan Kaki Pada Jalan Sudirman Kawasan Plaza Sukaramai-Mall Pekanbaru. JURNAL SAINTIS, 20(02), 93-100. https://doi.org/10.25299/saintis.2020.vol20(02).5542

Kurniawan, H., \& Ardi, N. K. (2018). Tingkat Kepuasan Pengguna Fasilitas Penyeberangan Orang (Studi Kasus Jpo Muka Kuning Kota Batam). SIGMA TEKNIKA, 1(2). https://doi.org/10.33373/sigma.v1i2.1501

Marga, D. B. (1995). Tata cara Perencanaan Fasilitas Pejalan Kaki di Kawasan Perkotaan.

Nadine, A., \& Imtiyaz, Z. Z. (2020). Analisis Upaya Pemerintah Dalam Menangani Mudik Melalui Peraturan Menteri Perhubungan Nomor 25 Tahun 2020 Pada Masa Covid-19. Media Iuris, 3(3), 277-298. https://doi.org/10.20473/mi.v3i3.20674

Prima, T. S., \& Prayogi, L. (2020). Kajian Perilaku Pejalan Kaki Pada Kawasan Transit Oriented Development (Tod). Jurnal Arsitektur ZONASI, 3(1), 1-10. https://doi.org/10.17509/jaz.v3i1.22842

Sandjaja, I. E., \& Purnamasari, D. (2017). Perancangan Kuisioner Survei Galangan. Technology Science and Engineering, 1(1), 27-33.

Wibowo, P. J., Syafaruddin, \& Sumiyattinah. (2019). Studi karakteristik pejalan kaki yang menggunakan jembatan penyeberangan orang di ruas jalan ahmad yani dan jalan rahadi usman kota pontianak. Jurnal Mahasiswa Teknik Sipil Universitas Tanjungpura, 6(1), 224-231. 